\title{
Impact of the Municipal Solid Waste Typology on Leachate Flow Under Semi-Arid Climate - A Case Study
}

\author{
Mourad Arabi ${ }^{1 *}$, Mohamed Sbaa ${ }^{1}$, Marnik Vanclooster ${ }^{2}$, Ahmed Darmous ${ }^{1}$ \\ 1 Laboratory of Water, Ecology and Sustainable Development, University Mohammed Premier, Faculty of \\ Sciences, BV Mohamed VI, PB 71760000 Oujda, Morocco \\ 2 Université Catholique de Louvain, Earth and Life Institute (ELI), GERU, Croix du Sud 2, 1348 Louvain La Neuve, \\ Belgium \\ * Corresponding author's e-mail: m.arabi@ump.ac.ma
}

\begin{abstract}
As recently created, the landfill site of Oujda, Morocco receives an annual flow of municipal solid wastes of 140000 tons. It became clear that the leachate storage ponds were undersized compared to the actually emanating flows. With no adequate treatment, the storage time of leachates in deep and anaerobic ponds increase and produce olfactory nuisances directly affecting the air quality of the nearest agglomerations. The monitoring of leachate flows during a year, showed the daily average production of $126 \mathrm{~m}^{3}$ (annual cumulative leachate is $46800 \mathrm{~m}^{3}$ ). Thus, highest volumes were recorded during the summer season $\left(4716 \mathrm{~m}^{3}\right.$ in July $4945 \mathrm{~m}^{3}$ in August, and $4927 \mathrm{~m}^{3}$ in September) with a monthly average rate of $3700 \mathrm{~m}^{3}$. In addition, the monitoring of leachate flows exhibits seasonal variations. Simultaneously, the MSW's typology and moisture content study showed the dominance of organic matter (73\%) and high moisture content $(63.5 \%)$. The results obtained are an essential asset for any decision in order to achieve appropriate leachates treatment with a possibility of recirculation into the landfill cells to enhance removal of their toxic contents.
\end{abstract}

Keywords: landfill, leachate, flow, municipal solid waste, characterization, Oujda, Morocco.

\section{INTRODUCTION}

Nowadays, the industrial and commercial progress in many countries over the world has been accompanied by rapid increases in both municipal and industrial waste generation. Indeed, over 242 million tons of municipal solid waste (MSW) were generated by the European Union countries in 2014, while 62 million tons were confined into landfills (Scarlat et al., 2019). The MSW management constitutes a major environmental, economical and social problem worldwide, mainly because the waste volume is growing faster than the world's population (Renou et al., 2008).

The sanitary landfilling is the worldwide common management method of MSW (Chu, 2008). It still preferred and used as the main applied method for the ultimate disposal of solid waste material, because of its low cost in middle or low-income countries. Besides its economic advantages (landfilling only requires 3 to $10 \mathrm{USD} /$ ton, compared to $10-100 \mathrm{USD} /$ ton to incinerate or compost waste), the sanitary landfilling reduces many environmental impacts and allows waste decomposition under controlled conditions until its eventual transformation into relatively inert and stabilized material (Renou et al., 2008). Additionally, the MSW quantity and quality variation follows several factors such as the socio-economic level and origin (urban vs. rural origin) of the waste, production season (Massarini and $\mathrm{Mu}-$ raro, 2015). Thus, in many developing countries where the waste collection rate is less than $50 \%$ and the sorting sector is still informal, the waste management chain experiences serious difficulties (Reddy, 2011). 
The greatest concern is the contamination of the surrounding ground and surface waters by toxic compounds (organic and inorganic) leached from the waste. Indeed, the pollution from landfills can have adverse effects on the local environment and is considered dangerous to human health (Scott et al., 2005). Disposal in landfills is considered as an effective method for waste management, but these disposal systems have some detrimental effects on the environment (Kim and Owens, 2010). It generates large quantities of leachates and odorous gases. These leachates, as the aqueous effluent being generated by excess rainwater percolating through waste layers, biochemical processes in waste's cells and the integral water content of wastes themselves, if not well controlled, cause a major source of surface and groundwaters alteration (Isidori et al., 2003). Certainly, a large quantity of these leachates is due to the waste composition. The organic fraction of Municipal Solid Waste (OFMSW) characterized by high moisture content and rich in biodegradable organic ingredients, has been recognized as a main valuable and convertible resource into useful products via microbial transformations (Yu and Huang, 2009). Moreover, the OFMSW potentially generates negative externalities in the landfilling systems, such as the spread of odor, greenhouse gas emission, huge leachate production and flux during the landfilling process (Hartmann et al., 2006; Wang et al., 2014). The climate has also a great influence on the leachate production because it affects the input of precipitation and losses through evaporation (Wang et al., 2004). Furthermore, the production of leachates depends on the nature of the waste itself, namely its water content and its degree of compaction into the cell. The production is generally greater whenever the waste is less compacted since compaction reduces the filtration rate (Renou et al., 2008). These factors affect both the quality and quantity of the leachate produced into landfills site (Serdarevic, 2018).

In Morocco, due to the demographic growth and urban expansion, the production of the MSW increases over the years (Ouigmane et al., 2017). The yearly waste production rate in Morocco reached 5.3 million tons $(0.76 \mathrm{~kg} / \mathrm{capita} / \mathrm{day})$ and 1.47 million tons per year $(0.28 \mathrm{~kg} / \mathrm{capita} /$ day $)$, in the urban and rural areas, respectively (SEDD, 2019). As a consequence, suitable solid waste management remains a priority concern for the Moroccan government (UNEP, 2014). Thus, it committed to developing waste management regulations with the solid waste law " 28.00 " run since 2006, and the implementation of the national plan for household waste management (PNDM) to reclaim all landfills and to recycle over $20 \%$ of the annual rate produced waste by 2020 (Naimi et al., 2017). The household waste produced in Morocco is largely dominated by Organic Mater (OM) (60-80\%), with over $75 \%$ of water content, which are at higher levels compared to countries in the same environmental context as Morocco and fully industrialized countries (Zouir, 2011). Until now, these MSW have generally undergone landfilling treatment with only $10 \%$ of recycling (SEDD, 2019).

At the recently created landfill site of the city of Oujda, Morocco, the annual flow of household waste recorded is 140000 tons, with a total accumulation of 1.6 million tons since the start-up in 2005. Thus, the MSW physical composition received on the landfill site of the city of Oujda is almost similar to other Moroccan cities, with a high proportion of organic matter $(73.3 \%)$ and humidity (81\%) (Saadi et al., 2013). The leachates from cells are continuously stored in evaporating ponds with no appropriate treatment ensued, thereby, it generates a negative impact on the surrounding environment quality, in particular with olfactory disturbances. Moreover, the designed capacity of these storage ponds is too low, explained by the underestimation of the leachates flows which are produced through the year due to the high organic matter contained in MSW.

This study conducted at the landfill site of Oujda city, (eastern of Morocco), during the year 2016, aimed at bringing out the effect of climate and the MSW composition on the leachate quantity and quality assessment at the landfill site of Oujda city. Thus, a flow-meter instrument was implanted in-situ, allowing the daily leachate quantity monitoring. The results obtained are an essential asset for the installation of the appropriate leachates treatment going to be implemented and will determine the possibility of recirculating these into the landfill site cells. 


\section{MATERIAL AND METHODS}

\section{Study area (landfill site)}

The landfill site of Oujda city, Morocco, is located at $34.57871 \mathrm{~N},-1.94221 \mathrm{~W}, 730 \mathrm{~m}$ altitude. This site has operated since October 2005 and covers a total surface area of 44 ha. Given the semi-arid climate dominating the study area, beside the average temperature values varying between $17^{\circ} \mathrm{C}$ (winter season) and $38^{\circ} \mathrm{C}$ (summer season), precipitation is less than $300 \mathrm{~mm} /$ year (Figure 3).

\section{MSW typology}

The MSW typology (physical composition) was conducted based on the French MODECOM $^{\mathrm{TM}}$ sampling standards methodology (Youb et al., 2014; Collaguazo et al., 2016). This approach defines the granulometric sizes as follows: a small fraction - less than $20 \mathrm{~mm}$, a middle fraction - between 20 and $100 \mathrm{~mm}$, and a long fraction of more than $100 \mathrm{~mm}$ (Wavrer et al., 2010). The MODECOM ${ }^{\mathrm{TM}}$ method makes a distinction between 13 categories of waste which are: 1.Putrescible waste (fraction consisting of food waste, green garden waste, etc.), 2. Paper, 3. Cardboard, 4. Textiles, 5. Sanitary textiles, 6. Plastics, 7. Complex waste (waste composed of several inseparable materials), 8 . Glass, 9. Metals, 10. Special household waste, 11. Thin elements $(<20 \mathrm{~mm}), 12$. Non-classified combustible waste (NCC), 13. Non-classified incombustible (NCI), which group together the waste which cannot be found in the other categories and which can only be distinguished as incinerable or not (Wavrer et al., 2010).
On the one hand, six samples of $100 \mathrm{~kg}$ collected over six representative distinct sub-areas of the city depending on a socioeconomic view (Comfortable, moderate and unfavourable standard of living). Then mixed to obtain the first subsample of $100 \mathrm{~kg}$ (MSW-city). Parallelly, six different samples obtained from waste trucks newly arrived on the landfill site, allowed to make the second sub-sample of $100 \mathrm{~kg}$ (MSW-Landfill). Thereby, both subsamples were mixed to build one major sample (MS) of $100 \mathrm{~kg}$ (Figure 1). In view of the seasonal effect on the MSW physical composition, this sampling operation was repeated for three different seasons of the year: the winter season, the spring season, and the summer season.

Accordingly, the major sample was sorted out by means of a sorting sieve which allowed separation in three size grading, namely: large fraction $(\mathrm{G} 1>100 \mathrm{~mm})$, moderate fraction $(100>\mathrm{G} 2<20 \mathrm{~mm})$ and the thin fraction $(G 3<20 \mathrm{~mm})$. Thus, each size grade sample was sorted in order to define its average physical composition, particularly its moisture content (by applying the quartering method) and its drying at $105^{\circ} \mathrm{C}$, successively, until the weight stabilization according to the AFNOR methods (French National Organization for Standardization) (Naïma et al., 2012).

\section{Leachate quantity}

The leachate quantity was measured using a Flow-meter instrument (Flo-logger, model 1000-1PC), implanted at the canal outlet of leachate to be evacuated in the storage pond $\mathrm{N}^{\circ} 3$ (Figure 1). The data collection was performed monthly, using a PC-connected data-logger.

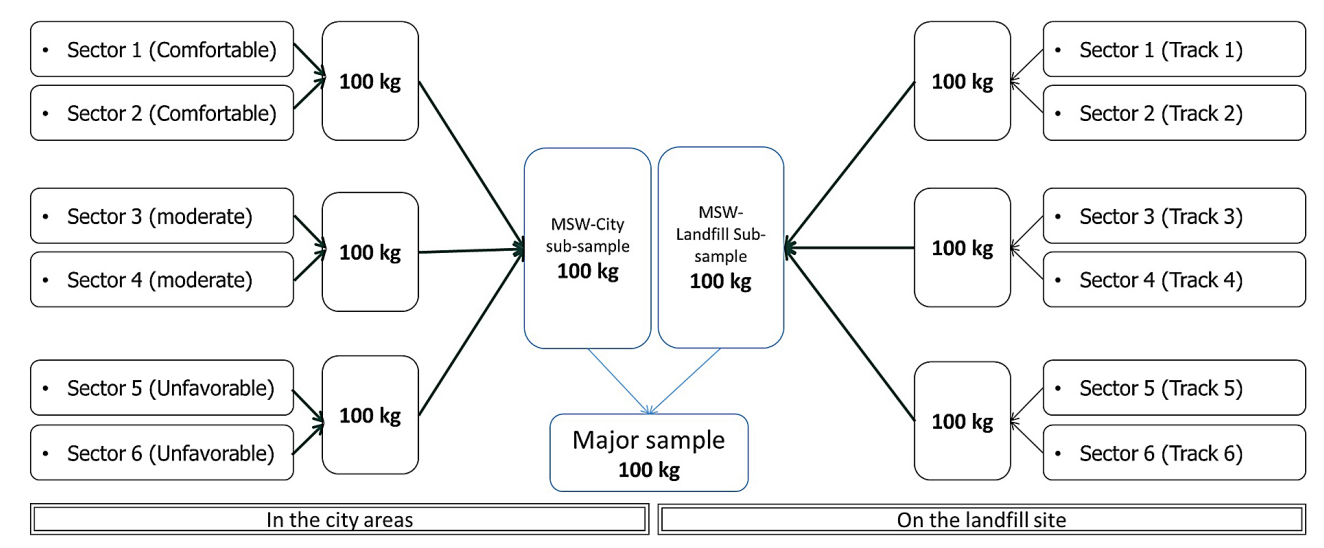

Figure 1. Schematic of applied waste sampling methodology 


\section{RESULTS AND DISCUSSION}

\section{MSW disposal quantity}

The new landfill site of the Oujda city received about 124000 tons of MSW per year from the urban prefectural area of Oujda Angad with a population of 480000 inhabitants (in 2005-2006), and the Benidrar town (a small urban centre located at $20 \mathrm{~km}$ from the city of Oujda) with a population of 11000 inhabitants (El Maguiri et al., 2016).

The MSW disposal rate in 2016 amounted to 152224 tons (the data was kindly provided by the archives of the landfill manager), given the served population ranging between 560000 and 580000 inhabitants (due to the significant presence of Moroccans residing abroad in the city of Oujda during the summer season).

The MSW disposed rate (2005-2016) is shown in (Figure 2). Currently, the landfill cells have received a total quantity of MSW which is 1.6 million tonnes since it has been operational. Thus, it seems very clear that the MSW production rate is directly affected by the demographic urban growth.

During the year of the current study (2016), the buried quantities of MSW varied in each month, ranging between 135000 and 147000 tons during the dry period (April to September), while their minimums rates (115000 tons) were recorded during the rainy periods (October to March) (Figure 3).

\section{MSW typology}

The MSW received at the Oujda city landfill are mainly generated by households. Their typology (physical composition expressed by weight $\%$, and humidity $\%$ ) is given in Table 1 .

Obviously, some small fluctuations among the organic proportion between the samples from the landfill site $(73 \%)$ and those sampled within urban areas $(69.8 \%)$ can be observed, due to the effect of informal recovery. Informal recovery and some recycling practices focus mainly on plastic, metal and cardboard part of MSW. As reported by Saadi et al. (2013), the organic fraction of MSW at the landfill of

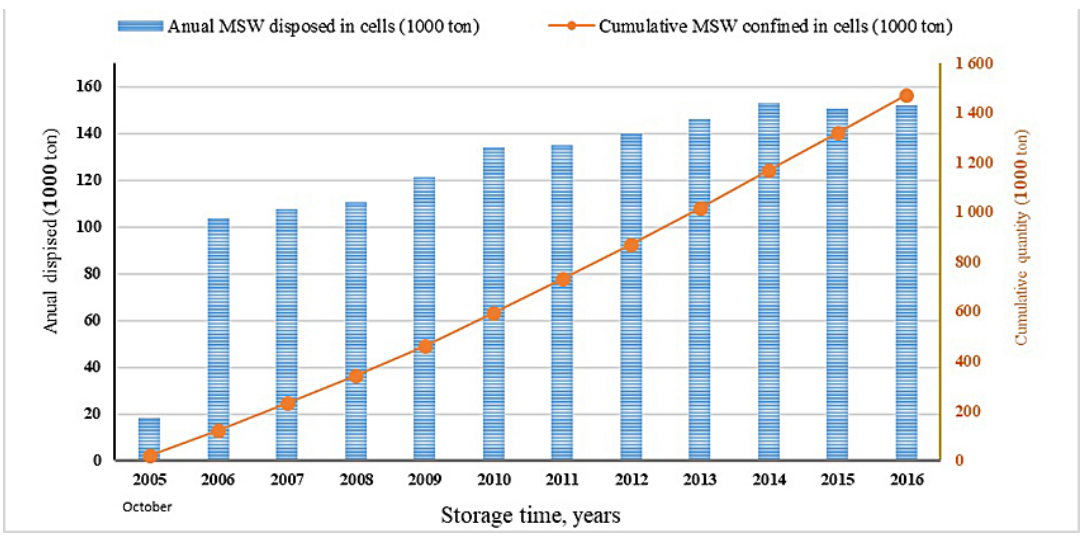

Figure 2. MSW disposed rate (2005-2016)

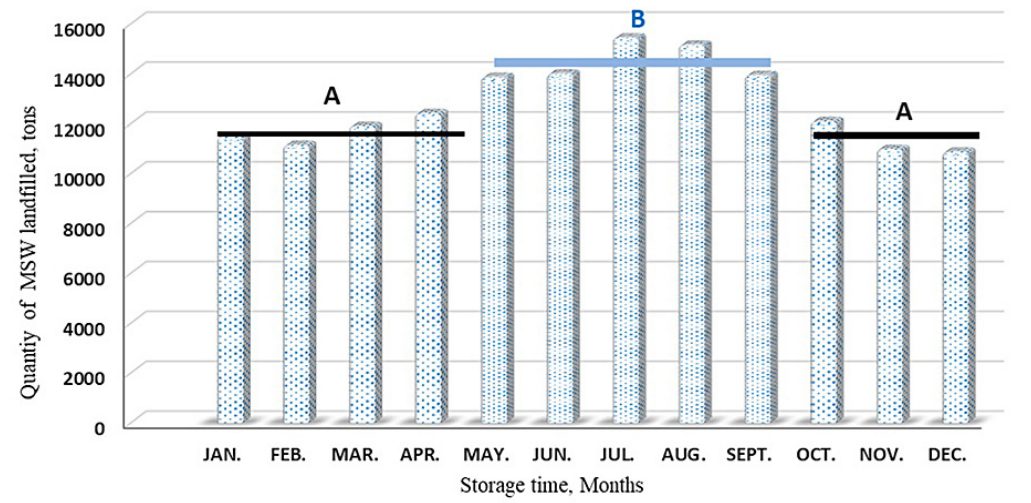

Figure 3: Time course of MSW disposed rate during one year (2016), A) rainy period, B) dry period 
Table 1. Typology of MSW (weight \% and humidity \%)

\begin{tabular}{|c|c|c|c|c|c|c|c|c|}
\hline \multirow{2}{*}{ Categories } & \multicolumn{2}{|c|}{ Campaign of February } & \multicolumn{2}{|c|}{ Campaign of May } & \multicolumn{2}{|c|}{ Campaign of August } & \multicolumn{2}{|c|}{ Average } \\
\hline & weight $\%$ & humidity $\%$ & weight $\%$ & humidity $\%$ & weight $\%$ & humidity $\%$ & weight $\%$ & humidity $\%$ \\
\hline $\begin{array}{l}\text { Putrescible waste } \\
\text { (fraction consisting } \\
\text { of food waste, green } \\
\text { garden waste, etc.) }\end{array}$ & 72.90 & 58.57 & 72.70 & 59.32 & 77.00 & 63.32 & 74.20 & 60.40 \\
\hline Cardboard & 2.71 & 1.39 & 4.10 & 3.04 & 1.33 & 0.66 & 2.71 & 1.70 \\
\hline The papers & 1.50 & 0.45 & 1.30 & 0.56 & 1.71 & 1.05 & 1.50 & 0.69 \\
\hline Sanitary textiles & 0.88 & 0.18 & 1.08 & 0.43 & 0.68 & 0.16 & 0.88 & 0.25 \\
\hline Textiles & 0.60 & 0.14 & 0.95 & 0.03 & 0.25 & 0.01 & 0.60 & 0.06 \\
\hline Thin elements $(<20 \mathrm{~mm})$ & 1.22 & 0.12 & 1.13 & 0.37 & 0.65 & 0.41 & 1.00 & 0.30 \\
\hline $\mathrm{NCC}^{*}$ & 0.55 & 0.05 & 0.75 & 0.13 & 0.35 & 0.10 & 0.55 & 0.09 \\
\hline Plastics & 8.62 & & 7.73 & & 9.52 & & 8.62 & \\
\hline Metals & 4.45 & & 4.00 & & 4.46 & & 4.30 & \\
\hline $\begin{array}{l}\text { Complex waste (waste } \\
\text { com-posed of several } \\
\text { inseparable materials) }\end{array}$ & 2.52 & & 1.00 & & 1.50 & & 1.67 & \\
\hline $\mathrm{NCl}^{* *}$ & 2.25 & & 3.19 & & 1.11 & & 2.18 & \\
\hline Glass & 1.55 & & 1.66 & & 1.44 & & 1.55 & \\
\hline Special household waste & 0.25 & & 0.41 & & 0.00 & & 0.22 & \\
\hline Total & 100.00 & 60.91 & 100.00 & 63.87 & 100.00 & 65.71 & 99.98 & 63.50 \\
\hline
\end{tabular}

Oujda was $(74 \%)$ in 2006 . Compared to other cities, the physical composition of MSW investigated in 2012 at Temara city (Western of Morocco), showed an organic mater amount of $63 \%$ followed by the paper or cardboard (16\%) then the plastics materials $(7.75 \%)$ (MEMEE, 2014), while in the landfill of Rabat city, the organic fraction ranges between $60-80 \%$ (Naimi et al., 2017). The reported organic matter in MSW is a national average of $64 \%$ (based on 2016 updated data) (SEDD. 2019).

Moreover, a significant deviation of the physical composition shown follows the seasons. Thus, in the summer season (2016), the sorted MSW gave the highest putrescible fraction $(77 \%)$ versus the lowest fraction $(72.7 \%)$ found in May 2016 (Table 1). The proportions of putrescible fraction obtained during the summer season (August-2016) are very high (77\%) with regard to those of the spring season (May2016) (72.2\%). A similar fermentable fraction (74\%) was found by Chiguer et al. (2016) at the landfill site of Essaouira city, Western Morocco. Additionally, a similar organic matter rate $(70 \%)$ was reported by (Mouhoun-Chouaki et al., 2019) at the landfill site of Marrakech city (south-centre of Morocco). Moreover, seasonal deviation found by Naïma et al. (2012) in a study conducted over the landfill site ChlefAlgeria, with a significant difference between the summer season $(77.2 \%)$ and winter season (64\%). Solid waste composition is the most significant factor governing the characteristics of a landfill. The knowledge on its nature (municipal or industrial waste) will govern the management practices and the pretreatment process. MSW may be directly deposited into a landfill (Scott et al., 2005).

As for the average moisture content (by weight: the weight of water/[weight of water + MSW]), it was significantly varying between seasons. For all campaigns, it reached an average rate of $63.5 \%$, mainly composed of the water contained in the organic fraction of MSW (60.4\%), thus confirming the important contribution this OFMSW to the leachate initially produced in landfill cells. Moreover, in summer (August), the humidity rate reached its maximum in the OFMSW with a percentage of $65.7 \%$ against a rate of $60.91 \%$ measured during winter (February). Similarely, Chiguer et al. (2016) reported that the measured moisture content in the MSW of Essaouira city, Morocco (transitional Mediterranean climate - towards desert) is an average of $70 \%$, as well as the moisture content found in the MSW of Chlef city, Algeria (Mediterranean climate), which is $60 \%$ but with a seasonal deviation of $\pm 15 \%$ (Naïma et al., 2012). 


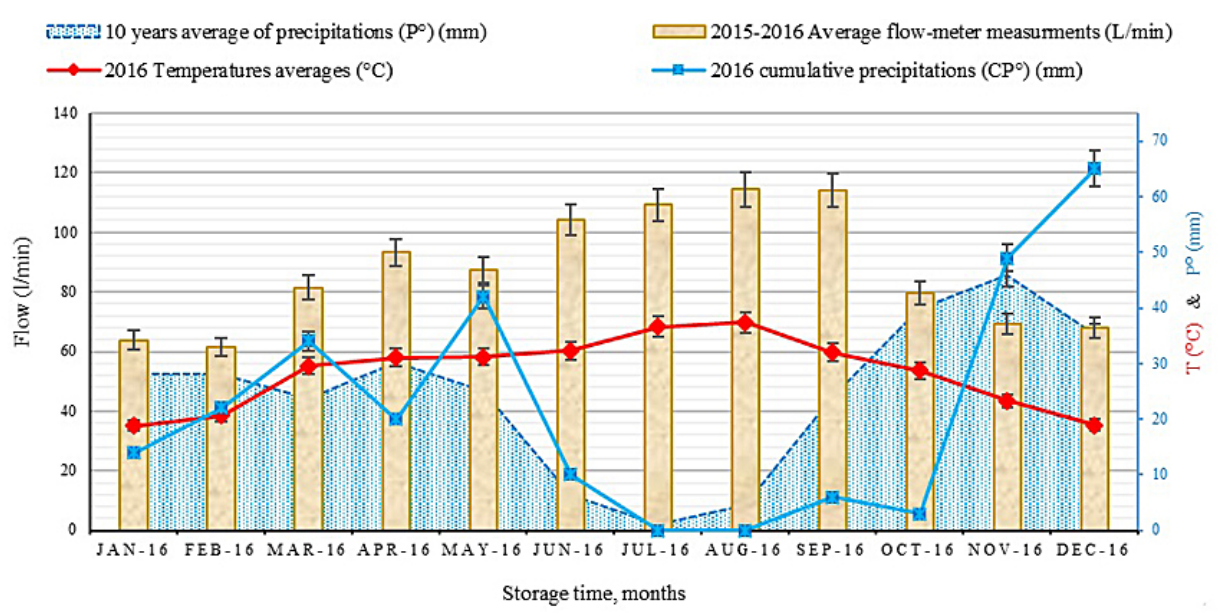

Figure 4. Leachate flow-rate compared to the Temperature and rainfall data.

\section{Leachate quantity (flowmeter)}

Despite rare precipitations recorded over the last years (low than $250 \mathrm{~mm} /$ year), the monitored leachate flow showed high levels, comparing to evaporating pond storage capacity $\left(27000 \mathrm{~m}^{3}\right)$. The flows reached an average of $126 \mathrm{~m}^{3} /$ day (with an accumulation of $46800 \mathrm{~m}^{3} /$ year). These values increase depending on the seasons. Maximum volumes were recorded in June, July, August and September with an average production of $4509 \mathrm{~m}^{3} / \mathrm{month}, 4716 \mathrm{~m}^{3} / \mathrm{month}, 4944 \mathrm{~m}^{3} /$ month, and $4927 \mathrm{~m}^{3} /$ month, respectively. The maximum leachate volumes are recorded at the same period of the highest MSW landfilled rates, and the lowest received precipitation amount. These explain that the leachate flow is directly impacted by the MSW generation rate and their typology, which undergoes monthly deviation according to many socioeconomic, industrial, and lifestyle factors (Naïma et al., 2012). Although the landfill site managers obtain these flow values using manual and estimative measures, it may cause under-dimensioning of leachate storage ponds. The timecourse leachate flow is given in (Figure 4).

The amount generated leachate and its extraction depend upon several factors, including solid waste composition, degree of compaction, the absorptive capacity of the waste and waste age, seasonal weather variations, levels of precipitation, landfill temperature, cells size, engineering, operational factors of the landfill and $\mathrm{pH}$ (Park et al., 2001; Di Iaconi et al., 2006). Precipitation and climate have the strongest influence on leachate generation, causing the amount to vary during the year (Wang et al., 2004).

\section{CONCLUSION}

The characterizing campaigns conducted for one year in the landfill site and in the urban area of Oujda city show that MSW are largely dominated by organic matters and high levels of moisture, which contributes to the increase in the water balance in the landfill. Consequently, the recorded flow of leachate continues to increase with the addition of other cells for newly disposed waste. Likewise, monitoring of results showed that the leachate flows are affected by the quantities of waste buried varying according to the seasons of the year. Indeed, the highest leachate flows recorded during the summer and spring seasons coincided with the maximum received waste amount. Hence, the importance of using precision monitoring tools in time as the used precision flowmeter for good dimensioning control of the new leachates storage ponds. Given the significant effect of the waste quantity and its physical composition on the characterized leachate flows assessement over the four seasons of the year, and through all the results obtained, it is highly recommended to adopt a specific pre-treatment approach for these leachates avoiding their continous release and accumulation into storage ponds.

\section{Acknowledgments}

The authors wish to thank the research teammates "Water, Environment, and health" at the laboratory of Water, Environment and Sustainable Development, The Faculty of Sciences Oujda city. The authors also acknowledge waste managers and stuff at the Oujda City Municipality and landfill site. 


\section{REFERENCES}

1. Chiguer, H., EL Khayyat, F. and EL Rhaouat, O., 2016. Evaluation de la charge polluante des déchets de la décharge contrôlée de la ville d'Essaouira (MAROC) (In French). Int. Journal of Innovation and Applied Studies. 14(3): 863-874.

2. Collaguazo, G., Badea, A., Stan, C., Pásztai, Z., 2016. Household wastes characterization and seasonal variations in Bihor County, Romania. UPB Sci. Bull. Ser. C Electr. Eng. Comput. Sci. 78, 281-290.

3. Di Iaconi, C., Ramadori, R., Lopez, A., 2006. Combined biological and chemical degradation for treating a mature municipal landfill leachate. Biochemical Engineering Journal. 31(2), 118-124. https://doi. org/10.1016/j.bej.2006.06.002

4. Maguiri, A., Zegzouti, Y., Souabi, S., Idrissi, L., El Hadek, M., Rene, E. R., Pala, A. I., Hafidi, M. (2016). 'LANDFILLS: Environmental impacts, assessment, and management in developing countries - the case of Morocco', in Chandler, N. (Ed.) LANDFILLS : Environmental Impacts, Assessment and Management. 2017th edn. New York: Nova Science Publishers, Inc., p. 297.

5. Isidori, M., Lavorgna, M., Nardelli, A., Parrella, A., 2003. Toxicity identification evaluation of leachates from municipal solid waste landfills: A multispecies approach. Chemosphere. 52(1), 85-94. https://doi. org/10.1016/S0045-6535(03)00298-4

6. Hartmann, H. and Ahring, B. K. (2006) 'Strategies for the anaerobic digestion of the organic fraction of municipal solid waste: An overview', Water Science and Technology, 53(8), pp. 7-22. https://doi. org/10.2166/wst.2006.231

7. Kim, K. and Owens, G., 2010. Potential for enhanced phytoremediation of landfills using biosolids - a review. Journal of Environmental Management. 91(4): 791-797. https://doi.org/https://doi. org/10.1016/j.jenvman.2009.10.017

8. Massarini, P. and Muraro P., 2015. RDF: From Waste to Resource- The Italian Case. Energy Procedia, 81(2015): 569-584. https://doi.org/10.1016/j. egypro.2015.12.136

9. MEMEE, 2014. Essais de caractérisation des déchets ménagers et assimilés réalisés au Maroc Résultats, synthèse et recommandations (In French). Rabat.

10. Mouhoun-Chouaki, S., Derridj, A., Tazdaït, D., Salah-Tazdaiit, R., 2019. A study of the impact of municipal solid waste on some soil physicochemical properties: the case of the landfill of Ain-ElHammam municipality, Algeria. Applied and Environmental Soil Science. 2019 : 8. https://doi. org $/ 10.1155 / 2019 / 3560456$

11. Naïma, T.D., Guy, M., Serge, C., Djamel, T., 2012. Composition of Municipal Solid Waste (MSW) generated by the city of Chlef(Algeria). Energy Procedia. 18(2012): 762-771. https://doi.org/10.1016/j. egypro.2012.05.092

12. Naimi, Y., Saghir, M., Cherqaoui, A., Chatre, B., 2017. Energetic Recovery of Biomass in the Region of Rabat, Morocco. International Journal of Hydrogen Energy. 42(2): 1396-1402. https://doi. org/10.1016/j.ijhydene.2016.07.055

13. Naveen, B.P., Mahapatra, D.M., Sitharam, T.G., Sivapullaiah, P.V., Ramachandra, T.V., 2017. Physico-chemical and biological characterization of urban municipal landfill leachate. Environmental Pollution. 220(2017): 1-12. https://doi.org/10.1016/j. envpol.2016.09.002

14. Ouigmane, A., Boudouch, O., Hasib, A., Berkani, M., Aadraoui, M., Dhairi, E., 2017. The Size Effect in the Distribution of Combustible Components in the Municipal Solid Waste Produced in the Summer time. Case of the City of Beni Mellal-Morocco. Journal of Materials and Environmental Science. 8(8): 2729-2737.

15. Park, S., Choi, K.S., Joe, K.S., Kim, W.H., Kim, H.S., 2001. Variations of landfill leachate's properties in conjunction with the treatment process. Environmental Technology (United Kingdom) 22: 639-645. https://doi.org/10.1080/09593332208618244

16. Reddy, J.P., 2011. Municipal solid waste management, Processing, Energy Recovery, Global Examples, 2011th ed, Routledge Handbook of Environmental Policy in China. BS publications. https://doi. org/10.4324/9781315736761

17. Renou, S., Givaudan, J.G., Poulain, S., Dirassouyan, F., Moulin, P., 2008. Landfill leachate treatment: Review and opportunity. Journal of Hazardous Materials. 150(3): 468-493. https://doi.org/10.1016/j. jhazmat.2007.09.077

18. Saadi, S., Sbaa, M., El kharmouz. M., 2013. Physico-Chemical Characterization of Oujda City Landfill Leachates (Eastern Morocco). ScienceLib. Editions Mersenne. 5(130517): 12. https://pdfs. semanticscholar.org/24c2/b41ae0ad98152194bc80abb653637af363ee.pdf

19. Scarlat, N., Fahl, F., Dallemand, J.F., 2019. Status and Opportunities for Energy Recovery from Municipal Solid Waste in Europe. Waste. Biomass and Valorization. 10(2019): 2425-2444. https://doi. org/10.1007/s12649-018-0297-7

20. Scott, J., Beydoun, D., Amal, R., Low, G., Cattle, J., 2005. Landfill management, leachate generation, and leach testing of solid wastes in Australia and overseas. Critical Reviews in Environmental Science and Technology. 35(3): 239-332. https://doi. org/10.1080/10643380590917969

21. SEDD, 2019. Stratégie Nationale de Réduction et de Valorisation des Déchets. Report (In French). Environnent Ministry, Morocco. 
22. Serdarevic, A., 2018. Landfill Leachate Management - Control and Treatment, in: Lecture Notes in Networks and Systems. pp. 618-632. https://doi. org/10.1007/978-3-319-71321-2_54

23. UNEP 2014. Emerging issues for Small Island Developing States. Results of the UNEP Foresight Process. United Nations Environment Programme (UNEP), Nairobi, Kenya.

24. Wang, L., Hung, Y., Lo, H., Yapijakis, C., 2004. Handbook of industrial and hazardous wastes treatment, 2nd ed. Boca Raton: CRC Press. https://doi. org/https://doi.org/10.1201/9780203026519

25. Wang, L., Shen, F., Yuan, H., Zou, D., Liu, Y., Zhu, B., Li, X., 2014. Anaerobic Co-digestion of kitchen waste and fruit/vegetable waste: labscale and pilot-scale studies. Waste Management. 34(12): 2627-2633. https://doi.org/10.1016/j. wasman.2014.08.005
26. Wavrer, P., Michel, P., Gidel, C., Védrine, H., 2010. Actualisation de la méthodologie MODECOMTM 6 Rapport final BRGM-RP-58939-FR. Orléans Cedex.

27. Youb, O., Youb, A., Bouabdessalam, H., 2014. Municipal Waste Management in the Algerian High Plateaus. Energy Procedia. 50(2014): 662-669. https://doi.org/10.1016/j.egypro.2014.06.081

28. Yu, H., Huang, G.H., 2009. Effects of Sodium Acetate as a PH Control Amendment on the Composting of Food Waste. Bioresource Technology 100(6): 2005-2011. https://doi.org/10.1016/j. biortech.2008.10.007

29.Zouir, A., 2011. Application des techniques d'échantillonnage passif pour l'évaluation de l'impact des fumées de la décharge municipale de tanger sur la qualité de l'air (In French). Ph.D. Thesis, University of Abdelmalek Essaadi, Tangier, Morocco. 